\title{
PHYTOSOCIOLOGICAL ASSESSMENT OF BROWSING VEGETATION IN ASSOCIATION WITH EDAPHIC FACTORS IN THE CHOLISTAN RANGELANDS OF PAKISTAN
}

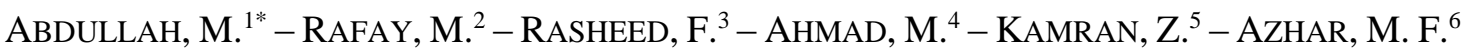 \\ - AKRAM, M. ${ }^{7}$-IHSAN, M. Z. ${ }^{1}-$ ALI, L. ${ }^{1}-$ AHMAD, T. I. ${ }^{8}$ \\ ${ }^{I}$ Cholistan Institute of Desert Studies (CIDS), The Islamia University of Bahawalpur, \\ Bahawalpur, Pakistan \\ ${ }^{2}$ Department of Forestry, Range and Wildlife Management, The Islamia University of \\ Bahawalpur, Bahawalpur, Pakistan \\ ${ }^{3}$ Department of Forestry and Range Management, University of Agriculture, Faisalabad, Pakistan \\ ${ }^{4}$ Department of Soil Science, The Islamia University of Bahawalpur, Bahawalpur, Pakistan \\ ${ }^{5}$ University College of Veterinary and Animal Sciences, The Islamia University of Bahawalpur \\ (IUB), Bahawalpur, Pakistan \\ ${ }^{6}$ Department of Forestry and Range Management, Bahauddin Zakariya University, Multan, \\ Pakistan \\ ${ }^{7}$ Department of Environmental Sciences, COMSATS Institute of Information Technology, Vehari, \\ Pakistan \\ ${ }^{8}$ Department of Economics, The Islamia University of Bahawalpur, Bahawalpur, Pakistan \\ *Corresponding author \\ e-mail: abdullahfrw@gmail.com; phone: +92-322-622-8229 \\ (Received $9^{\text {th }}$ Jan 2020; accepted $17^{\text {th }}$ Sep 2020)
}

\begin{abstract}
Rangelands are temporally and spatially unique socioecological systems supporting natural vegetation and livestock production. The browsing vegetation of Cholistan rangelands in Pakistan is degrading due to multiples stresses therefore a phytosociological survey was carried to determine the browse community structure and their association with edaphic features. In this study a total of 25 browse species belonging to 12 families and 17 genera were identified among which Chenopodiaceae, Mimosaceae, and Rhamnaceae were found to be the dominant families. According to vegetation analysis, twenty browse communities were documented based on the Importance Value Index (IVI) of each species. Multivariate analysis has delineated three vegetation associations inhabiting the sand-dune, interdune sandy and clayey saline habitats. Detrended Correspondence Analysis (DCA) of sites has maintained the coherency with vegetation groups identified by cluster analysis (CA). In Canonical Correspondence Analysis (CCA) soil electrical conductivity, sodium, organic matter, phosphorus, potassium were most important variables influencing range site distribution. Soil physicochemical analysis revealed that texture of sand-dune habitat was sandy; inter-dune was sandy loam while clayey saline was clayey. This study has revealed that browsing vegetation pattern was predominantly associated to soil attributes. Results showed that organic matter, and soil nutrients were better at inter-dune sandy habitat whereas $\mathrm{pH}$, electrical conductivity, sodium, and soil moisture were high at clayey saline habitat. The outcome of this research suggested that browse cover of Cholistan rangelands was under stress and varied according to seasons. Consequently, plant species with low IVIs need priority measures for conservation and those with high IVIs need monitoring ultimately to make these rangeland resources sustainable.
\end{abstract}

Keywords: range vegetation, degradation, physicochemical, multivariate, conservation 


\section{Introduction}

Understanding the associations among environmental variables in each ecosystem has strong applications in conservation and management (Zhou et al., 2016). In Range ecosystems, describing environmental variables which affect ecological process has been identified as main issue in plant ecology (Kong et al., 2015). Environmental factors perform vital role in determining spatial variation of biodiversity on broad geographical extent. Arid and semi-arid areas are mainly described by their sparse vegetation which makes them vulnerable to external or internal factors (Gharechelou et al., 2016). To examine vegetation structure and relationships between communities and their environment, quantitative classification and ordination have been broadly used (Li et al., 2018).

Assessing and monitoring are the first steps in understanding the ecological position of rangeland vegetation. Investigating the relationship between range plants and environmental variables has been the aim of many ecological studies. Ecologists have documented that environmental variables may control rangelands species composition and distribution (Briske et al., 2015). Rangelands cover about $40 \%$ of global land surface and are essentially the larger tracts of natural vegetation, used to support livestock (Holechek et al., 2011). Range livestock production at present supports the livelihood of an estimated 01 billion people and estimated 02 billion people depend on products from rangelands (Sayre, 2017). Majority of these rangelands are in vegetation biomes such as grasslands, shrublands, savannas, and deserts which are often characterized by arid climate (Friedel et al., 2000).

Pakistan is a sub-tropical country, and out of its total area (80 million ha) 49 million ha has been classified as rangelands which are almost consisting of arid to semiarid condition. The rangelands of Pakistan show a great diversity of species composition, structure, and productivity to support livestock (Majeed et al., 2002). Rangelands are very important because they provide vegetation cover, protection for soil, which also ensures sustainable production of animal feed. Especially browse plants (shrubs and tree foliage) beside grasses compose one of the cheapest sources of feed for animals in many parts of the World. Mostly browses have advantage of maintaining their nutrition and greenness during the dry season when grasses decline in both quantity and quality (Abdullah et al., 2013a).

In Pakistan, previous policies have always supported crops production over livestock, leading in the misuse of rangelands. Rangelands of Pakistan are degrading due to short growth period, over grazing, droughts, and marginal availability of productive species. The vegetation of these rangelands only flourishes in monsoon season, these problems are common everywhere in world where arid or semiarid rangelands exist. Therefore, developing countries like Pakistan face same situation in their rangeland's health (Harris, 2010). The rangelands of Pakistan are not managed by scientific approaches and presently, only $10-15 \%$ of their actual potential is being documented (Ali et al., 2001).

The desertification of rangelands does not refer to the spreading out of existing deserts, but to the process of land degradation in these natural ecosystems (Kong et al., 2015). Deserts are unique habitats, categorized by punishing temperature, extreme wind velocity, lack of moisture, high solar radiations and coarse topography where very limited species of animals and plants are adapted to stay alive (Van-Auken, 2000; McIntosh et al., 2019). A good percentage of human population in the subcontinent depend upon desert resources and increasing human population and communication links has extended the human misuse of these biotic resources (Middleton and Sternberg, 2013). 
The Cholistan desert was formerly a prosperous area but now largely converting into an abandoned patch. The productivity of its rangelands is degrading because the livestock number is increasing; ultimately, carrying capacity is decreasing. Sustainability of life in this hot desert rotates around the rainfall. During summer season, weather is tremendously severe and harsh; certain xeric plant species survive but suffer high grazing pressure. Resultantly, the palatable species are diminishing and unpalatable species with less nutritious properties are becoming abundant. Continuous increase in human population for livelihood and multiplying number of livestock is adding towards desertification (Arshad et al., 2001; Farazmand et al., 2019).

In Cholistan rangelands during summer season, nomadic pastoralists migrate with their cattle, sheep, and goats towards nearby canal-irrigated areas. However, a few male members of some clans remain in desert for their camel herds. These camels are seen everywhere in desert, browsing on different shrubs and tree species (Abdullah et al., 2017a). Due to year-round stress, the browses of Cholistan rangelands are under severe threat and need detail assessment. Therefore, it was urgently required to collect the base line data about browsing vegetation and based on this information to chalk out their conservation strategy.

To better manage the rangelands, it is very important to study the relation between vegetation and environmental factors (Brinkmann et al., 2009). Despite some previous work, mostly data are missing about the ecological aspects of Cholistan rangelands. Equally lacking are quantitative data about distribution of plant species, and their response to environment. The aim of this study was to analyses the browsing species composition and structure in Cholistan rangelands along environmental gradients. We hypothesize that environmental factors discriminate best between the vegetation types identified by a multivariate analysis and explain a high proportion in variability of plant species composition and structure.

\section{Material and methods}

\section{Research area}

This study was conducted in Cholistan desert of Pakistan which is a part of Great Indian desert (longitudes $69^{\circ} 52^{\prime}$ and $75^{\circ} 24^{\prime} \mathrm{E}$ and latitudes $27^{\circ} 42^{\prime}$ and $29^{\circ} 45^{\prime} \mathrm{N}$ ) covering an area of about 2.6 million ha (Fig. 1). It is an arid sandy desert where mean annual rainfall varies from less than $100 \mathrm{~mm}$ in west to $200 \mathrm{~mm}$ in east, mostly received in monsoon season (July to September). The mean summer temperature (May-July) is $34-38{ }^{\circ} \mathrm{C}$ with the highest reaching over $51.6^{\circ} \mathrm{C}$. The soil of Cholistan desert is mostly alkaline, saline, and gypsiferous composed of schists, gneiss, granites, and slates. Sand dunes are common in Cholistan and reach an average height of about $30 \mathrm{~m}$ to $100 \mathrm{~m}$. Cholistan contains large alluvial saline flats (locally called dahars) alternating with low sandy ridges. These soils are classified as either saline or saline sodic, with $\mathrm{pH}$ ranging from 8.2 to 8.4 and from 8.8 to 9.6 , respectively. The vegetation of this desert consists of xerophytes, adjusted to low moisture, extremely hot temperature, and more salinity with wide variation of edaphic factors (Abdullah et al., 2017b).

\section{Phytosociological survey and analysis}

A reconnaissance survey was conducted in January 2014, to have an impression of site conditions, accessibility, overview of plant assemblages and to determine the sampling 
and data collection methods. According to schedule, whole research project was carried for two consecutive years i.e. 2014 and 2015. After going through the topographic map of area followed by frequent visits during initial stages of study, research area was divided into 20 sites to cover the variations of physiognomy and physiography (Fig. 1). Name of each sampling site, topography, and coordinates are given in Table 1.

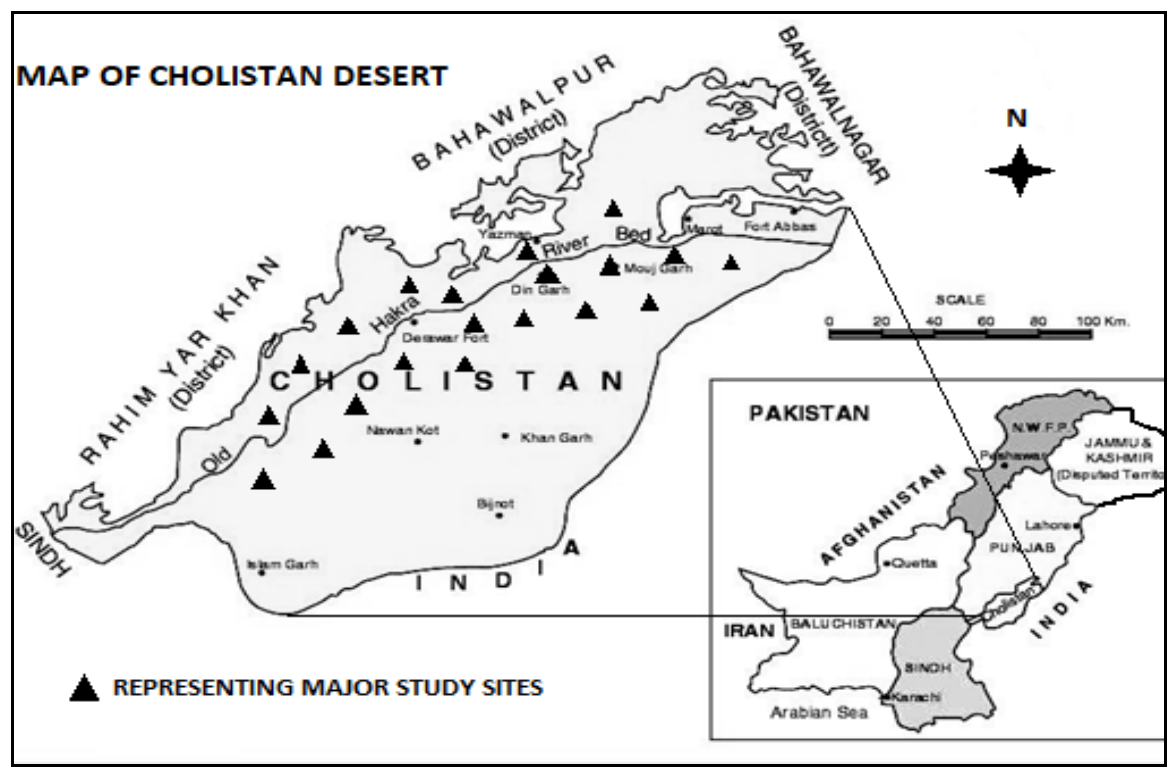

Figure 1. Map of study area; the Cholistan desert of Pakistan

Table 1. Name, location, and topography of each survey site in study area

\begin{tabular}{|c|c|c|c|c|c|}
\hline Sr. No. & Site name & Topography & Elevation & Latitude & Longitude \\
\hline 1 & Mansora & Sand-dune & $121 \mathrm{~m}$ & $\mathrm{~N}: 29^{\circ} 12.161^{\prime}$ & E: $072^{\circ} 15.427^{\prime}$ \\
\hline 2 & Kalapahar & Clayey saline & $117 \mathrm{~m}$ & $\mathrm{~N}: 29^{\circ} 10.430^{\prime}$ & E: $072^{\circ} 05.569^{\prime}$ \\
\hline 3 & Chaklihar & Inter-dune sandy & $119 \mathrm{~m}$ & $\mathrm{~N}: 29^{\circ} 11.315^{\prime}$ & E: $071^{\circ} 57.648^{\prime}$ \\
\hline 4 & Januwali & Inter-dune sandy & $124 \mathrm{~m}$ & $\mathrm{~N}: 29^{\circ} 05.056^{\prime}$ & E: $072^{\circ} 09.933^{\prime}$ \\
\hline 5 & Khirsir & Sand-dune & $119 \mathrm{~m}$ & $\mathrm{~N}: 29^{\circ} 10.339^{\prime}$ & E: $072^{\circ} 08.749^{\prime}$ \\
\hline 6 & Haider wali & Clayey saline & $116 \mathrm{~m}$ & $\mathrm{~N}: 29^{\circ} 02.672^{\prime}$ & E: $072^{\circ} 10.200^{\prime}$ \\
\hline 7 & Mojgarh Fort & Sand-dune & $119 \mathrm{~m}$ & $\mathrm{~N}: 29^{\circ} 01.059^{\prime}$ & E: $072^{\circ} 08.106^{\prime}$ \\
\hline 8 & Chelanwala Toba & Inter-dune sandy & $112 \mathrm{~m}$ & $\mathrm{~N}: 28^{\circ} 57.261^{\prime}$ & E: $072^{\circ} 03.089^{\prime}$ \\
\hline 9 & Khanser & Sand-dune & $107 \mathrm{~m}$ & $\mathrm{~N}: 28^{\circ} 59.227^{\prime}$ & E: $071^{\circ} 55.299^{\prime}$ \\
\hline 10 & Aldin Mor & Inter-dune sandy & $104 \mathrm{~m}$ & $\mathrm{~N}: 28^{\circ} 47.988^{\prime}$ & E: $071^{\circ} 45.770^{\prime}$ \\
\hline 11 & Dingarh Fort & Clayey saline & $111 \mathrm{~m}$ & $\mathrm{~N}: 28^{\circ} 57.454^{\prime}$ & E: $071^{\circ} 51.910^{\prime}$ \\
\hline 12 & Dingarh Fort & Sand-dune & $113 \mathrm{~m}$ & $\mathrm{~N}: 28^{\circ} 57.182^{\prime}$ & E: $071^{\circ} 49.362^{\prime}$ \\
\hline 13 & Nidamwala Toba & Clayey saline & $108 \mathrm{~m}$ & $\mathrm{~N}: 28^{\circ} 52.963^{\prime}$ & E: $071^{\circ} 44.270^{\prime}$ \\
\hline 14 & Mehmodwala Toba & Inter-dune sandy & $102 \mathrm{~m}$ & $\mathrm{~N}: 28^{\circ} 47.939^{\prime}$ & E: $071^{\circ} 45.770^{\prime}$ \\
\hline 15 & Lakhan & Clayey saline & $107 \mathrm{~m}$ & $\mathrm{~N}: 28^{\circ} 52.232^{\prime}$ & E: $071^{\circ} 42.731^{\prime}$ \\
\hline 16 & Chananpir & Inter-dune sandy & $108 \mathrm{~m}$ & $\mathrm{~N}: 28^{\circ} 56.832^{\prime}$ & E: $071^{\circ} 40.057^{\prime}$ \\
\hline 17 & Baylawala & Inter-dune sandy & $125 \mathrm{~m}$ & $\mathrm{~N}: 29^{\circ} 23.466^{\prime}$ & E: $071^{\circ} 39.563^{\prime}$ \\
\hline 18 & Derawar fort & Sand-dune & $102 \mathrm{~m}$ & $\mathrm{~N}: 28^{\circ} 49.208^{\prime}$ & E: $071^{\circ} 28.129^{\prime}$ \\
\hline 19 & Derawar fort & Inter-dune sandy & $105 \mathrm{~m}$ & $\mathrm{~N}: 29^{\circ} 23.465^{\prime}$ & E: $071^{\circ} 39.560^{\prime}$ \\
\hline 20 & Chasma Dhar & Clayey saline & $098 \mathrm{~m}$ & $\mathrm{~N}: 28^{\circ} 39.864^{\prime}$ & E: $071^{\circ} 15.632^{\prime}$ \\
\hline
\end{tabular}


Analytic phase (Botanical survey) was concerned with acquisition of all relative vegetation data, present in the sites. Phytosociological parameters consisting of frequency, density and plant cover are considered necessary for complete analysis of vegetation. To calculate the quantitative vegetation parameters, Line Transect and Quadrate methods were used (Mueller-Dumbois and Ellenberg, 1974; Chul and Moody, 1983) as shown in the layout Figure 2. The importance Value (IV) for each species was calculated by direct summation of relative density, relative frequency, and relative cover. The specific site position (latitude, longitude, and altitude) was determined by a GPS (Global Positioning System) named Garmin eTrex.

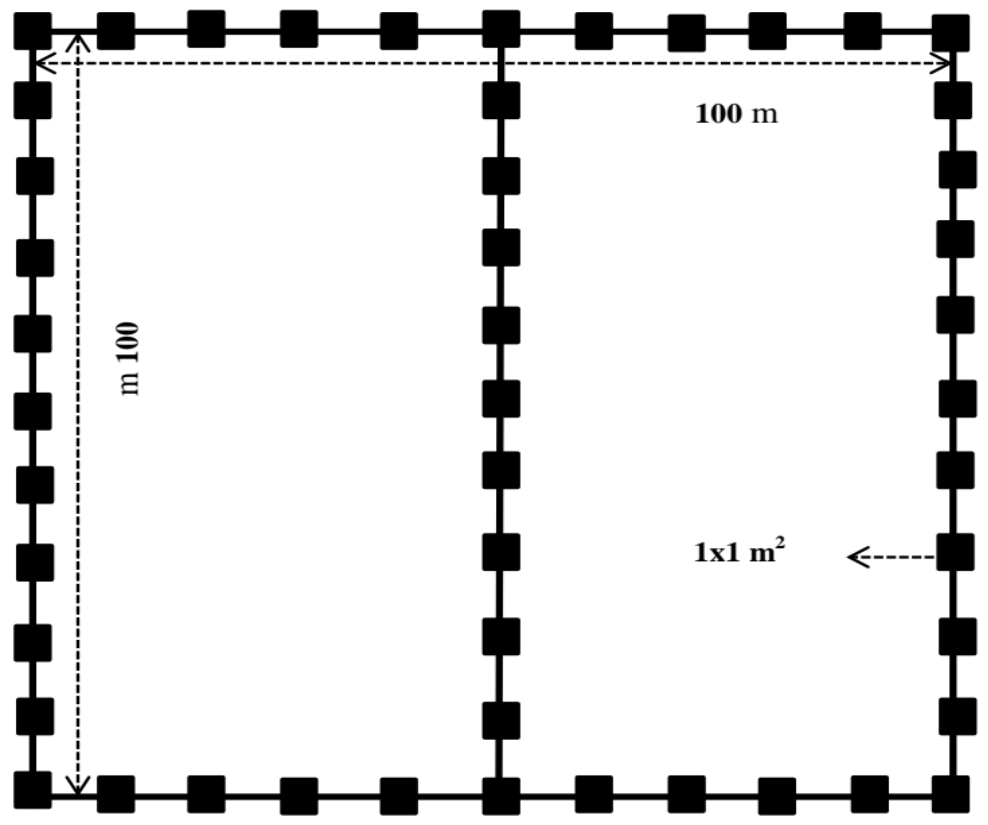

Figure 2. Layout of data collection method at each site (05 transect of each $100 \mathrm{~m}$ length with quadrat of $1 \times 1 \mathrm{~m}^{2}$ on $10 \mathrm{~m}$ interval)

Synthetic phase (Data analysis) follows the classification of data to obtain groupings of communities based on floristic and structural similarities. The arrangement of surveyed data and mathematical classification was obtained by using the multivariate statistical program MVSP Ver. 3.2 (Kovach 1985-2002). The vegetation classification was made using IVI based data and name of communities were given after two or three dominant species with higher synoptic values. The ordination techniques (DCA, CCA) were also applied to dataset to provide evidence for possible gradients in and between communities and to detect habitat gradients that may be associated with vegetation analyses, and to identify environment plant interactions.

\section{Soil analysis}

For soil analysis, soil sample of $1 \mathrm{~kg}$ was collected along each transect from the depth of 0-30 cm. Five soil samples are collected from each site and these samples were pooled together to form one composite sample, air-dried, thoroughly mixed, and passed through $2 \mathrm{~mm}$ sieve to liberate it from gravel and boulders. The collected samples were stored in polythene bags and labeled for physical and chemical analysis in soil laboratory (Head, 2006). 


\section{Results}

\section{Classification}

According to phytosociological survey twenty types of browse communities were identified based on Importance value index of each species, on three different landforms in Cholistan rangelands. Cluster analysis was used to classify the vegetation of Cholistan rangelands into relatively homogeneous groups of range sites by using importance value index of each species. Here results have been presented in form of dendrogram (Fig. 3) which has delineated three vegetation associations inhabiting the sand dunes, inter-dune sandy patch, and clayey saline flats. Pictogram images of three desert habitats have been shown in Figure 4.

In Sand-dune association (Cluster A) six sites were included i.e., 1, 5, 7, 9, 12, and 18, as shown in Figure 3. This association was comprised of six browse communities while the habitat of these sites was sand dune. Total 21 plant species were recorded in this association out of which there were six browse species. In sand-dune association dominant browse species were Calligonum polygonoides (IV $=60.78)$ and Haloxylon salicornicum (IV = 59.85) while Aerva javanica (IV =14.43) Crotalaria burhia $(\mathrm{IV}=12.79)$ and Leptadenia pyrotechnica (IV = 10.75) were associated species (Table 2). Physicochemical analysis of soil showed that texture of this association was sandy with $\mathrm{pH} 8$, electrical conductivity (EC) 1.63 , soil moisture $0.39 \%$ and organic matter was $0.32 \%$. The concentration of sodium $(\mathrm{Na})$, potassium $(\mathrm{K})$, phosphorus $(\mathrm{P})$, was calculated as $18.15 \mathrm{ppm}, 29.54 \mathrm{ppm}$ and $3.93 \mathrm{ppm}$ respectively (Table 3).

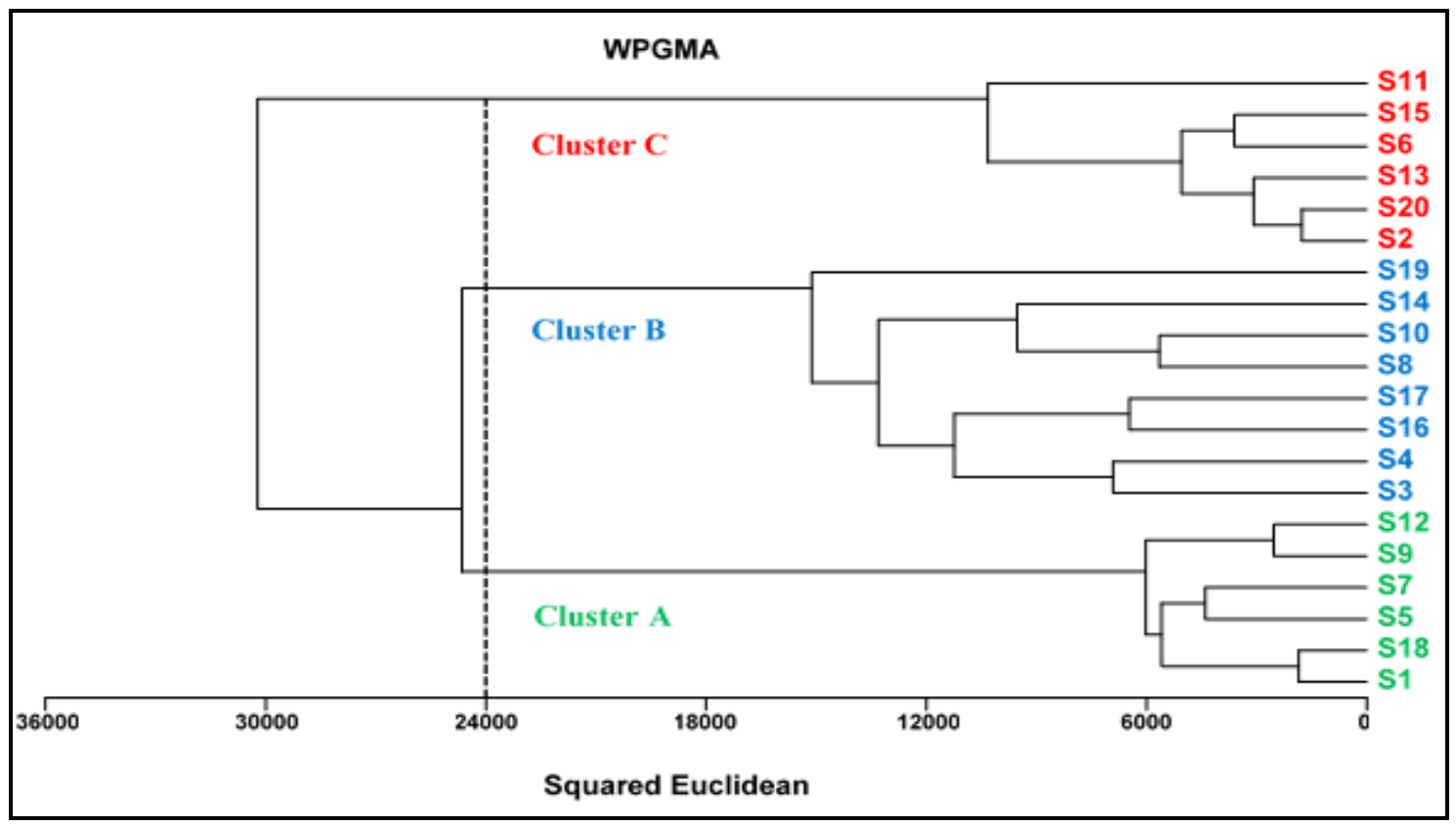

Figure 3. Dendrogram from cluster analysis of 20 range sites representing $A=$ sand-dune association, $B=$ inter-dune sandy association, $C=$ clayey saline association

Inter-dune sandy association (Cluster B) was consisting of eight sites including 3, 4, $8,10,14,16,17$, and 19 (Fig. 3). The habitat of these sites was inter-dune sandy. In this cluster, total 38 plant species were present out of which 13 species were browses. This association was comprised of eight browse communities, whereas most dominant 
browse species was Leptadenia pyrotechnica $(\mathrm{IV}=46.40)$ followed by Aerva javanica $(\mathrm{IV}=42.14)$ Crotalaria burhia (IV = 41.33) and Salsola baryosma $(\mathrm{IV}=37.82)$ respectively. However, Haloxylon salicornicum $(\mathrm{IV}=26.36)$ Capparis deciduas $(\mathrm{IV}=22.85)$ Calotropis procera $(\mathrm{IV}=20.81)$ Calligonum polygonoides $(\mathrm{IV}=20.68)$ were considered as associated species (Table 2). Soil texture of this association was sandy loam with $\mathrm{pH} 08.25$ and EC 03.61. The contents of Na, K, P, were calculated as $32.22 \mathrm{ppm}, 56.60 \mathrm{ppm}$ and $5.97 \mathrm{ppm}$ respectively, whereas soil moisture was $0.63 \%$ and organic matter was $0.74 \%$ (Table 3).

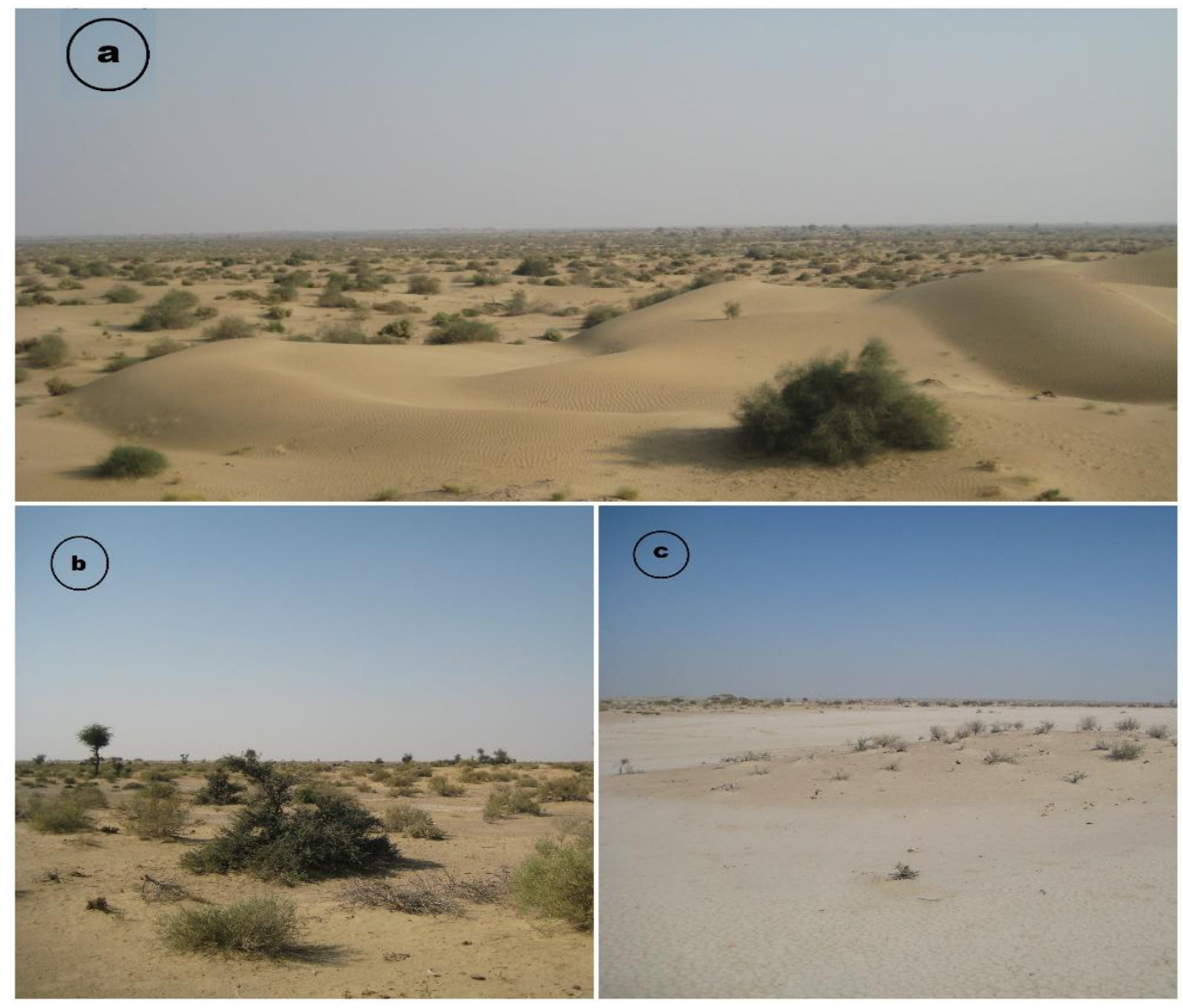

Figure 4. Pictorial image of $a=$ sand-dune association, $b=$ inter-dune sandy association, $c=$ clayey saline association

Clayey saline association (Cluster C) was consisting of six sites i.e. 2, 6, 11, 13, 15, 20, as shown in Figure 3. This association was comprised of six browse communities and habitat of these stands was clayey saline. Total 23 plant species were observed in this association in which 11 species were browses, whereas dominant browse species were Suaeda fruticosa $(\mathrm{IV}=79.02)$ and Haloxylon recurvum $(\mathrm{IV}=75.25)$ while Salsola baryosma (IV $=39.38)$ Calotropis procera $(\mathrm{IV}=20.68)$ Pulicaria rajputanae $(\mathrm{IV}=15.60)$, Abutilon muticum (IV = 13.79) Tephrosia uniflora (IV = 13.24) were associated species (Table 2). Based on soil analysis of these sites, soil texture was clayey with $\mathrm{pH} 8.46$ and EC 10.98. The concentration of $\mathrm{Na}, \mathrm{K}, \mathrm{P}$, was $77.29 \mathrm{ppm}$, $22.61 \mathrm{ppm}$ and $2.49 \mathrm{ppm}$ respectively, whereas soil moisture was $0.84 \%$ and organic matter was $0.20 \%$ (Table 3). 
Table 2. Mean importance values of plant species in three associations

\begin{tabular}{|c|c|c|c|c|c|}
\hline Sr. No. & Plant species & $\mathbf{A}$ & $\mathbf{B}$ & $\mathbf{C}$ & Habit \\
\hline 1 & Abutilon muticum (Del. ex. DC.) Sweet. & 0 & 12.52 & 13.79 & Shrub \\
\hline 2 & Acacia nilotica (Linn.) Del & 0 & 2.74 & 0 & Tree \\
\hline 3 & Aeluropus lagopoides (Linn.) Trin. ex Thw. & 0 & 0 & 28.26 & Grass \\
\hline 4 & Aerva javanica (Burm. f.) Merill & 14.43 & 42.14 & 0 & Shrub \\
\hline 5 & Aristida adscensionis Linn. & 0 & 5.20 & 0 & Grass \\
\hline 6 & Calligonum polygonoides Linn. & 60.78 & 20.68 & 0 & Shrub \\
\hline 7 & Calotropis procera (Aiton.) Aiton. & 0 & 20.81 & 20.68 & Shrub \\
\hline 8 & Capparis decidua (Forsskal.) Edgew. & 0 & 22.85 & 10.97 & Shrub \\
\hline 9 & Cenchrus biflorus Roxb. & 5.99 & 0 & 0 & Grass \\
\hline 10 & Cenchrus ciliaris Linn. & 28.84 & 10.14 & 0 & Grass \\
\hline 11 & Cenchrus setigerus Vahl. & 0 & 7.89 & 0 & Grass \\
\hline 12 & Chrozophora plicata (Vahl) A. Juss. ex Spreng. & 4.00 & 3.12 & 0 & Herb \\
\hline 13 & Citrulus colocynthis (Linn.) Schrad. & 3.19 & 2.23 & 0 & Herb \\
\hline 14 & Convolvulus microphyllus Sieb. ex Spreng. & 0 & 0 & 3.13 & Herb \\
\hline 15 & Corchorus depressus (Linn.) Stocks & 0 & 2.32 & 4.55 & Herb \\
\hline 16 & Crotalaria burhia Buch. Ham. ex Benth. & 12.79 & 41.33 & 0 & Shrub \\
\hline 17 & Cymbopogon jwarancusa (Jones) Schult. & 0 & 29.67 & 40.89 & Grass \\
\hline 18 & Dipterygium glaucum Decne. & 62.74 & 44.41 & 0 & Herb \\
\hline 19 & Euphorbia prostrata Ait. & 2.03 & 1.84 & 2.50 & Herb \\
\hline 20 & Fagonia cretica Linn. & 0 & 7.94 & 10.90 & Herb \\
\hline 21 & Farsetia hamiltonii Royle & 15.15 & 1.54 & 0 & Herb \\
\hline 22 & Gisekia pharnaceoides Linn. & 0 & 1.87 & 0 & Herb \\
\hline 23 & Glinus lotoides Linn. & 0 & 0 & 1.68 & Herb \\
\hline 24 & Haloxylon recurvum Bunge. ex. Boiss. & 0 & 0 & 75.25 & Shrub \\
\hline 25 & Haloxylon salicornicum (Moq.) Bunge. & 59.85 & 26.36 & 0 & Shrub \\
\hline 26 & Heliotropium crispum Desf. & 0 & 11.18 & 10.34 & Herb \\
\hline 27 & Lasiurus scindicus Henr. & 29.22 & 19.91 & 0 & Grass \\
\hline 28 & Leptadenia pyrotechnica (Forssakal.) Decne. & 10.75 & 46.40 & 0 & Shrub \\
\hline 29 & Limeum indicum Stocks. ex. T. Anderson & 10.14 & 3.32 & 0 & Herb \\
\hline 30 & Mollugu cerviana $($ L.) Seringe & 2.16 & 1.13 & 0 & Herb \\
\hline 31 & Ochthochloa compressa (Forssk.) Hilu & 0 & 41.03 & 9.25 & Grass \\
\hline 32 & Pennisetum devisum (Gmel.) Henr. & 0 & 25.64 & 0 & Grass \\
\hline 33 & Panicum turgidum Forssk. & 44.14 & 30.67 & 0 & Grass \\
\hline 34 & Polygala erioptera DC. & 1.36 & 1.34 & 0 & Herb \\
\hline 35 & Prosopis cineraria (Linn.) Druce. & 1.47 & 2.91 & 0 & Tree \\
\hline 36 & Pulicaria rajputanae Blatt. \& Hollb & 0 & 0 & 15.60 & Herb \\
\hline 37 & Salsola baryosma (Roem. et. Scult.) Dany. & 0 & 37.82 & 39.38 & Shrub \\
\hline 38 & Salvadora oleoides Decne. & 0 & 0 & 2.59 & Tree \\
\hline 39 & Sesuvium sesuvioides (Fenzl.) Verdc. & 2.62 & 2.22 & 0 & Herb \\
\hline 40 & Solanum surattense Burm. f. & 0 & 2.07 & 4.16 & Herb \\
\hline 41 & Sporobolus iocladus (Nees ex Trin.) Nees & 0 & 31.51 & 41.26 & Grass \\
\hline 42 & Stipagrostis plumose (Linn.) Munro ex T. Anderss. & 10.13 & 11.20 & 0 & Grass \\
\hline 43 & Suaeda fruticose (Linn.) Farsskal. & 0 & 2.14 & 79.02 & Shrub \\
\hline 44 & Tamarix aphylla (Linn.) Karst. & 0 & 0 & 2.62 & Tree \\
\hline 45 & Tephrosia uniflora (Linn.) Pers. & 0 & 2.21 & 13.24 & Shrub \\
\hline 46 & Tribulus longipetalus Viv. subsp. macropterus (Boiss.) & 1.81 & 2.45 & 0 & Herb \\
\hline 47 & Zaleya pentendra Linn. & 0 & 0 & 2.47 & Herb \\
\hline 48 & Zizyphus mauritiana Lam. & 0 & 0 & 2.54 & Tree \\
\hline
\end{tabular}


Table 3. Summary statistics of environmental variables (soil) at three associations $($ mean $\pm S D)$

\begin{tabular}{c|c|c|c|c|c|c|c|c|c|c}
\hline Assoc. & $\begin{array}{c}\text { Depth } \\
\mathbf{~ c m}\end{array}$ & $\mathbf{p H}$ & $\begin{array}{c}\mathbf{E C} \\
\mathbf{d s} / \mathbf{m}\end{array}$ & $\begin{array}{c}\mathbf{N a} \\
\mathbf{p p m}\end{array}$ & $\begin{array}{c}\mathbf{K} \\
\mathbf{p p m}\end{array}$ & $\begin{array}{c}\mathbf{P} \\
\mathbf{p p m}\end{array}$ & $\begin{array}{c}\text { Soil } \\
\mathbf{m o i s t u r e} \\
\mathbf{\%}\end{array}$ & $\begin{array}{c}\text { Organic } \\
\text { matter } \\
\mathbf{\%}\end{array}$ & $\begin{array}{c}\text { Saturation } \\
\mathbf{\%}\end{array}$ & Texture \\
\hline $\mathrm{A}$ & $0-30$ & $8.00 \pm 0.09$ & $1.63 \pm 0.47$ & $18.15 \pm 2.82$ & $29.54 \pm 2.27$ & $3.92 \pm 0.28$ & $0.39 \pm 0.07$ & $0.32 \pm 0.05$ & $17.67 \pm 1.21$ & Sandy \\
$\mathrm{B}$ & $0-30$ & $8.25 \pm 0.08$ & $3.61 \pm 0.86$ & $32.22 \pm 3.79$ & $56.60 \pm 11.59$ & $5.97 \pm 1.09$ & $0.63 \pm 0.07$ & $0.74 \pm 0.15$ & $34.87 \pm 9.80$ & Sandy loam \\
$\mathrm{C}$ & $0-30$ & $8.46 \pm 0.08$ & $10.98 \pm 1.0$ & $77.29 \pm 10.04$ & $22.61 \pm 2.23$ & $2.49 \pm 0.38$ & $0.84 \pm 0.07$ & $0.20 \pm 0.02$ & $61.83 \pm 0.98$ & Clayey \\
\hline
\end{tabular}

$\mathrm{A}=$ sand-dune association, $\mathrm{B}=$ inter-dune sandy association, $\mathrm{C}=$ clayey saline association, EC=electrical conductivity, $\mathrm{Na}=$ sodium, $\mathrm{K}=$ potassium, $\mathrm{P}=$ phosphorus, $\mathrm{SD}$ standard deviation

\section{Ordination}

In ordination, (correspondence analysis) DCA ordination (indirect gradient analysis) and CCA ordination (direct gradient analysis) procedures of multivariate statistical methods were used.

\section{Detrended correspondence analysis (DCA)}

The distribution of 20 sites along first axis and second axis of detrended correspondence analysis is represented in Figure 5. DCA analysis of sites has maintained the coherency with vegetation groups identified by cluster analysis (CA). However, scatter graph is easily interpretable in ecological terms. Stands situated to the left of diagram were representing the sand-dune association (A) and stands situated more to the right of diagram were showing the clayey saline association (C). While the stands in-between them were showing the inter-dune sandy association (B). This graph illustrates a gradient along ordination axes 01 which could be related to high $\mathrm{pH}, \mathrm{EC}$, $\mathrm{Na}$ and soil moisture in right side at association $\mathrm{C}$ and low in left side with association A. Summary of detrended correspondence analysis is given in Table 4.

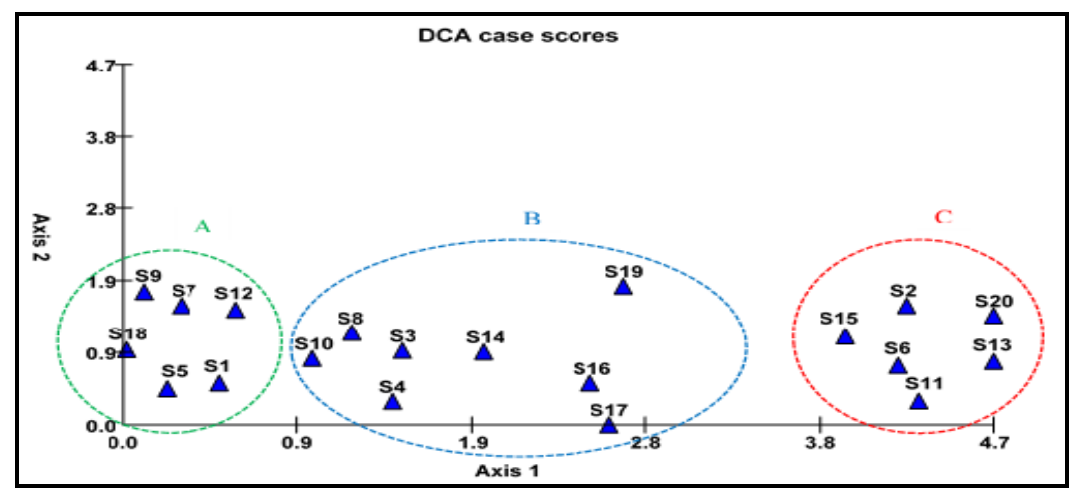

Figure 5. Detrended correspondence analysis (DCA) of range sites showing $A=$ sand-dune association, $B$ = inter-dune sandy association, $C=$ clayey saline association

Table 4. Summary of detrended correspondence analysis (DCA)

\begin{tabular}{c|c|c|c|c}
\hline Axis & Axis 1 & Axis 2 & Axis 3 & Axis 4 \\
\hline Eigenvalues & 0.823 & 0.157 & 0.084 & 0.052 \\
Percentage & 34.193 & 6.526 & 3.482 & 2.152 \\
Cum. percentage & 34.193 & 40.719 & 44.201 & 46.353 \\
\hline
\end{tabular}




\section{Canonical correspondence analysis (CCA)}

To determine the overall pattern of plant species and sites distribution based on environmental factors, CCA ordination was performed on a medium containing importance values of species ( $\mathrm{n}=48$ species) in 20 sites. In biplot (Fig. 6), points were representing individual stands and arrow representing soil variables. The length and direction of an arrow representing a given environmental factor provide a sign of importance and direction of gradient of environmental change for that factor. Long arrow was more closely correlated in ordination than those with short arrow and was much significant in influencing the variations in community. Perpendicular vegetation associations near to or beyond the tip of arrows will be strongly correlated and influenced by an arrow while those at opposite end will be less affected.

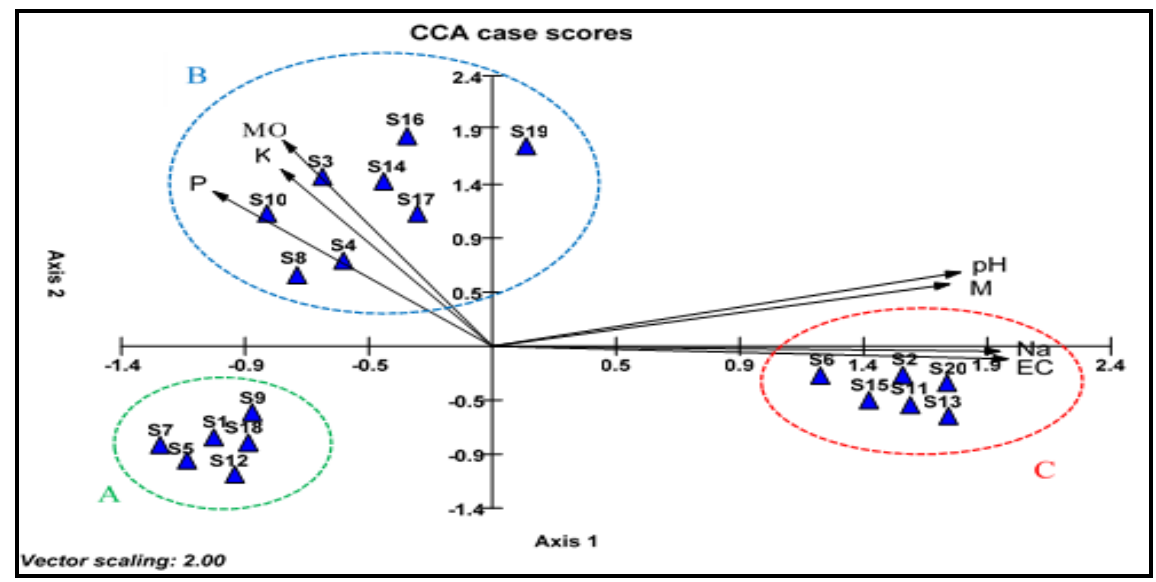

Figure 6. CCA biplot of range sites with environmental (soil) variables showing $A=$ sand-dune association, $B=$ inter-dune sandy association, $C=$ clayey saline association. $(E C=$ electrical conductivity, $\mathrm{Na}=$ sodium, $K=$ potassium,$P=$ phosphorus, $O M=$ organic matter ,

$$
M=\text { moisture) }
$$

The angle between an arrow and each axis reflects its degree of correlation with axis. The eigenvalues of CCA axis are given in Table 5. The first two axes are most important in elucidating the variations in floristic data because these explain $100 \%$ variation. As first two axes are standards for determining the variation in data, hence variables that strongly correlate with these axes were considered as most important environmental factors. The continuous decrease of the eigenvalues along the CCA axes has stated a well-structured data set. In CCA of range sites EC, Na, OM, P, K, were most important variables influencing the sites distribution. While going through the axis 01 and 02, some stands were assembled on negative side of axis 01 away from the origin of the axis under the effect of EC and $\mathrm{Na}$. Whereas some stands were scattered on positive side of axis 02 under the influence of $\mathrm{OM}, \mathrm{P}$, and $\mathrm{K}$. It was observed, electrical conductivity and sodium were more towards the long arrow having strong correlation and portraying some significant role in grouping of sites.

\section{Discussion}

Multivariate procedures are often used to analyze the species composition and their relationships with environmental factors both quantitatively and qualitatively (Kargar 
Chigani et al., 2012). This study has quantitatively classified and ordinated the browsing vegetation with environmental factors (soil) in Cholistan Rangelands of Pakistan. The browse community structure was relatively simple with drought and salt-tolerant plant species. Though there was relatively low biodiversity in study area, variation in the species diversity may be explained by the spatial heterogeneity of habitat and environment (Zhang et al., 2005). Effects of environmental factors on plant communities have been the subject of many ecological studies. It has long been recognized that relationship between plant communities and soil characteristics is a key issue for the ecological restoration of Rangelands (Liu. et al., 2018).

Table 5. Summary of canonical correspondence analysis (CCA)

\begin{tabular}{c|c|c|c|c|c}
\hline Axis & Axis 1 & Axis 2 & Axis 3 & Axis 4 & Axis 5 \\
\hline Eigenvalues & 0.77 & 0.355 & 0.08 & 0.069 & 0.065 \\
Percentage & 31.958 & 14.734 & 3.324 & 2.846 & 2.695 \\
Cum. percentage & 31.958 & 46.693 & 50.016 & 52.862 & 55.557 \\
Cum. constr. percentage & 54.266 & 79.284 & 84.928 & 89.76 & 94.336 \\
Spec.-env. correlations & 0.974 & 0.918 & 0.883 & 0.768 & 0.788 \\
\hline
\end{tabular}

The assessment of vegetation in Cholistan rangelands has documented total 25 browse species, not all identified species were used in the classification of plant communities. There were total twenty browse communities recognized in the twenty range sites of Cholistan desert (Abdullah et al., 2013b). In the studied area, woody and perennial species almost remained same whereas shape of community changed due to the prevalence of annuals species during monsoon, which shows seasonal aspect. Bredenkamp and Brown (2003) agreed that differences in floristically defined plant communities were mostly linked with habitat variables such as topography (landform, aspect, and slope), geology, and altitude, although soil texture, and depth are also necessary components.

According to results, cluster analysis has classified the twenty range sites into three different vegetation clusters. Cluster A was consisting of sand-dune association, cluster $\mathrm{B}$ was consisting of inter-dune sandy association and cluster $\mathrm{C}$ was consisting of clayey saline association. Generally, these clusters were representing the three ecological habitats i.e. sand-dune, inter-dune and clayey saline in Cholistan rangelands. Results showed that vegetation diversity was poor at sand-dune habitat because soil texture was sandy and mostly consisted of unstabilized sand dunes. Sand-dune association was comprising of six browse communities i.e. Haloxylon salicornicum-Calligonum polygonoides-Leptadenia pyrotechnica, Calligonum polygonoides-Haloxylon salicornicum-Crotalaria burhia, Haloxylon salicornicum-Calligonum polygonoidesAerva javanica, Calligonum polygonoides-Haloxylon salicornicum-Aerva javanica, Calligonum polygonoides-Haloxylon salicornicum-Leptadenia pyrotechnica and Haloxylon salicornicum-Calligonum polygonoides-Crotalaria burhia. Earlie Arshad and Akbar (2002) have reported related results who have studied the benchmark plant communities of Cholistan desert.

Inter-dune habitat was consisting of small hummocks of sand and vegetation cover was better. This association was comprised of eight browse communities i.e. Leptadenia pyrotechnica-Aerva javanica-Crotalaria burhia, Crotalaria burhia-Leptadenia pyrotechnica-Haloxylon salicornicum, Crotalaria burhia-Aerva javanica-Haloxylon 
salicornicum, Aerva javanica-Crotalaria burhia-Calligonum polygonoides, Salsola baryosma-Crotalaria burhia-Haloxylon salicornicum, Salsola baryosma-Leptadenia pyrotechnica-Capparis deciduas, Leptadenia pyrotechnica-Salsola baryosma-Haloxylon salicornicum and Aerva javanica-Salsola baryosma-Calotropis procera. Whereas clayey saline association was consisting of six browse communities i.e. Haloxylon recurvumSuaeda fruticosa-Pulicaria rajputanae, Suaeda fruticosa-Haloxylon recurvum-Salsola baryosma, Suaeda fruticosa-Salsola baryosma-Haloxylon recurvum, Haloxylon recurvum-Suaeda fruticosa-Tephrosia uniflora, Haloxylon recurvum-Suaeda fruticosaCalotropis procera and Suaeda fruticosa-Haloxylon recurvum-Abutilon muticum. In this association, vegetation diversity was low due salinity and poor organic contents in soil. Similar results have been reported by Akhter and Arshad (2006) who has studied the rangelands plant communities in Cholistan desert.

The results of cluster analysis were verified by detrended correspondence analysis. DCA of sites data has produced the similar vegetation groupings along the axis as identified by the cluster analysis (CA). The three habitats were clearly discernible in ordination diagram along the two axes. Results showed that group of range sites situated to the left of the diagram was representing the sand-dune association and sites situated more to the right of the diagram were showing with clayey saline association whereas sites in-between them were representing the inter-dune association. The DCA graph has illustrated a gradient along ordination axes 1 that could be related to high $\mathrm{pH}, \mathrm{EC}, \mathrm{Na}$, and soil moisture in right side at clayey saline association (C) and low in left side at sand-dune association (A).

Subsequently the effect of environmental variables on three vegetation associations was carried out by canonical correspondence analysis. Ordination technique CCA has described the overall pattern of plant species and sites distribution based on soil variables. In CCA biplot the most effective soil variables, which have significant correlation with the distribution of vegetation associations were organic matter, phosphorus, potassium, electrical conductivity, and sodium. Result showed that interdune association (B) was strongly correlated with organic matter, potassium, and phosphorus whereas clayey saline association (C) was under the strong impact of EC and $\mathrm{Na}$. It was observed that, sand-dune association (A) was located at opposite end of the high EC, $\mathrm{Na}, \mathrm{pH}$, and soil moisture, indicating the poor effect of these environmental variables. Arshad et al. (2008) has also reported that edaphic factors has strong influence in distribution plant communities in Cholistan desert.

Physiochemical analysis of soil has revealed that concentration of organic matter, potassium and phosphorus was better at association (B), therefor vegetation was also healthier at inter-dune sandy habitat. However, soil nutrient level was poor both at sanddune (A) and clayey saline associations, further poor vegetation in these associations was be due to moving sand dunes problem and high salinity level, respectively. Overall, this multivariate analysis has sketched out the vegetation of Cholistan rangelands into three distinct associations: sand-dune, inter-dune sandy and clayey saline along with their specific soil features. To study the vegetation of Cholistan rangelands, much stress was paid on plant communities. The vegetation of Cholistan desert has not been studied properly however, our work confirms the findings of some earlier researchers in this area such as Arshad and Akbar (2002), Akhter and Arshad (2006) and Arshad et al. (2008).

Analyzing the ecological data by using multivariate methods makes simple understanding of complex relationship between plants and environmental gradients (McGranahan et al., 2013). Various studies have investigated the relationship between 
environmental factors and vegetation such as Zare et al. (2011), Mohtashamnia et al. (2011), Wang et al. (2012), McGranahan et al. (2013), Kargar-Chigani et al. (2017), Li et al. (2018) and Eghdami et al. (2019) have showed that soil strongly influence on vegetation formations. Distribution pattern of desert plants and their relationship to soil in Cholistan rangelands by using classification and ordination resulted in a clear display of spatial variability of plant communities. Our results provided the theoretical basis for vegetation conservation, which had laid a foundation for the sustainable development of research area. These results have important implications for management and conservation of rangelands in the context of ongoing climate change. Finally, the use of long-term monitoring which integrate field surveys, climate data, remote sensing, and multivariate context could be a useful tool for range managers with early signs for the onset of desertification (Davis et al., 2020).

\section{Conclusion}

This assessment has created a detail map about the status of browsing vegetation in relation to soil variables in Cholistan rangelands. Understanding the indicator of environmental factors of a given site leads us to recommend highly adapted species for improvement of that site. Previously no comprehensive study was reported therefore, present research provided a valuable baseline data on browse species of this arid ecosystem. Disturbed study sites require an immediate protection and species with low importance value index (IVI) needs conservation and those with high IVIs needs monitoring. Actions should be taken to address the problems faced by those species having low importance value index. This data should be incorporated into the current management plan which should serve as a valuable tool in the planning, conservation, and management of these rangelands. All factors considered, it was concluded that browsing species of Cholistan were under stress and they need proper rehabilitation through ecological approaches. Future studies should be focused on determining biological and physical properties of soil, collection of climatic data and protection of endangered species. Consequently, when managing the desert like environment in Pakistan or in world, consideration of appropriate soil factors that ensure biodiversity and ecosystem functions are very important.

Acknowledgments. This work was part of Ph.D. thesis of Mr. Muhammad Abdullah. Authors thankfully acknowledge support from Higher Education Commission (HEC) Pakistan under indigenous scholarship program. Authors are also grateful to Late Dr. Muhammad Arshad (Ex. Director Cholistan Institute of Desert Studies) for his valuable supervision during whole work.

\section{REFERENCES}

[1] Abdullah, M., Rashid. A. K., Shahid, Y., Munir, A. (2013a): Mineral profile of browse species used as feed by grazing livestock in Cholistan rangelands, Pakistan. - Pak. J. Nut. 12: $135-143$.

[2] Abdullah, M., Rashid. A. K., Shahid, Y., Munir, A. (2013b): Community structure of browse vegetation in Cholistan rangelands of Pakistan. - Pak. J. Agri. Sci. 50(2): 237247. 
[3] Abdullah, M., Muhammad, R., Nuzhat, S., Fahad, R., Muhammad, F. N., Wasif, N., Irfan, A., Tahira, R., Sangam, K. (2017a): Determination of forage productivity, carrying capacity and palatability of browse vegetation in arid rangelands of Cholistan Desert (Pakistan). - App. Ecol. Env. Res. 15: 623-637.

[4] Abdullah, M., Muhammad, R., Tanveer, H., Hussain, A., Usman, T., Fahad, R., Tahira, R., Sangam, K. (2017b): Nutritive and palatability potential of browse foliage by livestock from arid rangelands of Cholistan Desert. - J. Ani. Pla. Sci. 27: 1656-1664.

[5] Akhter, R., Arshad, M. (2006): Arid rangelands in Cholistan Desert Pakistan. - Sche. 17: $1-18$.

[6] Ali, M., Qamar, I. A., Ali, A., Arshad, M., Iqbal, J. (2001): Evaluation of tropical grasses for forage yield and crude protein content in the Pothowar plateau of Pakistan. - Online J. Biol. Sci. 1: 466-7.

[7] Arshad, M., Akbar, G. (2002): Benchmark of plant communities of Cholistan Desert. Pak. J. Biol. Sci. 10: 1110-1113.

[8] Arshad, M., Rao, A. R., Akbar, G. (2001): Sustainability pattern of livestock in Cholistan desert Pakistan. - Sustainable Development of Desert Communities - a Regional Symposium, Iran, UNDP 2: 185-192.

[9] Arshad, M., Hassan, A. U., Ashraf, M. Y., Noureen, S., Moazzam, M. (2008): Edaphic factors and distribution of vegetation in the Cholistan desert, Pakistan. - Pak. J. Bot. 40: 1923-1931.

[10] Bredenkamp, G. J., Brown, L. R. (2003): A reappraisal of Acock's Bankenveld: origin and diversity of vegetation types. - Sou. Afri. J. Bot. 69: 7-26.

[11] Brinkmann, K., Annette, P., Uta, D., Eva, S., Andreas, B. (2009): Vegetation patterns and diversity along an altitudinal and a grazing gradient in the Jabal al Akhdar mountain range of northern Oman. - Journal of Arid Environments 73: 1035-1045.

[12] Briske, D. D., Joyce, L. A., Polley, H. W., Brown, J. R., Wolter, K., Morgan, J. A., McCarl, B. A., Bailey, D. W. (2015): Climate-change adaptation on rangelands: linking regional exposure with diverse adaptive capacity. - Frontiers in Ecology and the Environment 13: 249-256.

[13] Chul, K. S., Moody, K. (1983): Comparison of some methodologies for vegetation analysis in transplanted rice. - Kor. J. Crops Sci. 28: 310-318.

[14] Davis, K. P., David, J. A., Adrian, P. M., Justin, D. D., Cameron, L. A. (2020): Adaptive rangeland management benefits grassland birds utilizing opposing vegetation structure in the shortgrass steppe. - Ecological Applications 30(01).

[15] Eghdami, H., Ghanimat, A., Philippe, L., Hossein, A. (2019): Impact of land use changes on soil and vegetation characteristics in Fereydan, Iran. - Agriculture 9(58): 1-17.

[16] Farazmand, A., Arzani, H., Javadi, S. A., Sanadgol, A. A. (2019): Determining the factors affecting rangeland suitability for livestock and wildlife grazing. - Applied Ecology and Environmental Research 17(1): 317-329.

[17] Friedel, M. H., Laycock, W. A., Bastin, G. N. (2000): Assessing Rangeland Condition and Trend. - In: t'Mannetje, L., Jones, R. (eds.) Field and Laboratory Methods for Grassland and Animal Production Research. CABI International, Wallingford, UK, pp. 305-360.

[18] Gharechelou, S., Tateishi, R., Sharma, R. C., Johnson, B. A. (2016): Soil moisture mapping in an arid area using a land unit area (LUA) sampling approach and geostatistical interpolation techniques. - Int. J. Geo-Inf. 5(35).

[19] Harris, R. B. (2010): Rangeland degradation on the Qinghai-Tibetan plateau: a review of the evidence of its magnitude and causes. - J. of Ari. Envir. 74: 1-12.

[20] Head, K. H. (2006): Manual of Soil Laboratory Testing. 3rd Ed. - Whittles Publishing, London.

[21] Holechek, J. L., Piper, R. D., Herbel, C. H. (2011): Range Management Principles and Practices. Sixth Ed. - Pearson/Prentice Hall, Upper Saddle River, NJ. 
[22] Kargar-Chigani, H., Khajeddin, S. J., Karimzadeh, H. R. (2012): Soil-vegetation relationships of three arid land plant species and their use in rehabilitating degraded sites. - Land Degradation \& Development 23(1): 92-101.

[23] Kargar-Chigani, H., Seyed, A. J., Ghavamodin, Z., Seyed, J. K., Mohamad, J. (2017): Vegetation composition differentiation and species-environment relationships in the northern part of Isfahan Province, Iran. - J Arid Land 9(2): 161-175.

[24] Kong, T. M., Stuart, E. M., Andre, F. V. R., Klaus, K., Barron, J. O. (2015): Assessing rangeland condition in the Kalahari Duneveld through local ecological knowledge of livestock farmers and remotely sensed data. - Journal of Arid Environments 113: 77-86.

[25] Kovach, W. (1985-2002): Institute of Earth Studies, University College of Wales, ABERYSTWYTH, (Shareware) MVSP Version 3.2. - Kovach Computing Services http://www.kovcomp.com/MVPs/downl2.html.

[26] Li, S., Su, P., Zhang, H., Zhou, Z., Xie, T., Shi, R., Gou, W. (2018): Distribution patterns of desert plant diversity and relationship to soil properties in the Heihe River Basin, China. - Ecosphere 9(7).

[27] Liu, S., Xiaoyun, H., Min, Y., Fangyan, C., Ana, C., Xue, W., Yueqiu, Z. (2018): Factors driving the relationships between vegetation and soil properties in the Yellow River Delta, China. - Catena 165: 279-285.

[28] Majeed, A., Azam, M., Mumtaz, A. (2002): Drought and Water Management Strategies in Pakistan. - Proceedings of the SAARC Workshop on Drought and Water Management Strategies. September 16-18, 2002 Lahore-Pakistan. Pakistan Council of Research in Water Resources, Islamabad, Pakistan.

[29] McGranahan, D. A., David, M. E., Samuel, D. F., James, R. M., Diane, M. D. (2013): Multivariate analysis of rangeland vegetation and soil organic carbon describes degradation, informs restoration and conservation. - Land 2: 328-350.

[30] McIntosh, M. M., Jerry, L. H., Sheri, A. S., Andres, F. C., Richard, E. E. (2019): LongTerm declining trends in Chihuahuan Desert forage production in relation to precipitation and ambient temperature. - Rangeland Ecology \& Management 72: 976-987.

[31] Middleton, N., Sternberg, T. (2013): Climate hazards in drylands: a review. - Earth Sci. Rev. 126: 48-57.

[32] Mohtashamnia, S., Ghavemoddin, Z., Hossein, A. (2011): Multivariate analysis of rangeland vegetation in relation to edaphical and physiographical factors. - Procedia Environmental Sciences 7: 305-310.

[33] Mueller-Dombois, D., Ellenberg, H. (1974): Aims and Methods of Vegetation Ecology. Wiley, New York.

[34] Sayre, N. F. (2017): The Politics of Scale: A History of Rangeland Science. - University of Chicago Press, Chicago, IL.

[35] Van-Auken, O. W. (2000): Shrub invasions of Northern American semi-arid grasslands. Annu. Rev. of Ecol. Syst. 31: 197-215.

[36] Wang, Z. R., Yang, G. J., Chen, S. Y., Wu, Z., Guan, J. Y., Zhao, C. C., Zhao, Q. D., Ye, B. S. (2012): Effects of environmental factors on the distribution of plant communities in a semi-arid region of the Qinghai-Tibet Plateau. - Ecol. Res. 27: 667-675.

[37] Zare, S., Jafari, M., Tavili, A., Abbasi, H., Rostampour, M. (2011): Relationship between environmental factors and plant distribution in arid and semiarid area (case study: Shahriyar rangelands, Iran). - Am. Eurasian J. Agric. Environ. Sci. 10: 97-105.

[38] Zhang, Y. M., Chen, Y. N., Pan, B. R. (2005): Distribution and floristics of desert plant communities in the lower reaches of Tarim River, southern Xinjiang, People's Republic of China. - Journal of Arid Environment 63: 772-784.

[39] Zhou, J., Fu, B. J., Gao, G. Y., Lü, Y. H., Liu, Y., Lu, N., Wang, S. (2016): Effects of precipitation and restoration vegetation on soil erosion in a semi-arid environment in the Loess Plateau, China. - Catena 137: 1-11. 